\title{
The Development of Learning Media of Pakakala Boardgame
}

\author{
Kamaruddin Hasan $^{1}$, Zaid Zainal ${ }^{2}$, Suhadjerah ${ }^{3}$ \\ ${ }^{1}$ Elementary School Teacher Education, Universitas Negeri Makassar, Indonesia \\ Email: Kamaruddinhasan.1973@gmail.com \\ ${ }^{2}$ Elementary School Teacher Education, Universitas Negeri Makassar, Indonesia \\ Email: zainal.zaid@gmail.com \\ ${ }^{3}$ Elementary School Teacher Education, Universitas Negeri Makassar, Indonesia \\ Email: Suhadjerahk@gmail.com
}

(Received: January-2020; Reviewed: January-2020; Accepted: March-2020;

Available online: March 2020; Published: April-2020)

\begin{abstract}
This study aims to develop a learning media in the form of boardgame Learning Media (Optional Board and Career Cards) to improve students' career knowledge in a fun, interactive and active learning under. This research uses Research and Development Method, with The phases in this research consist of; (1) product analysis, (2) developing products, (3) validation and revision, (4) play-trials and final products. Data collection techniques using interviews and questionnaires. Feasibility check and assessment by theory expert, learning media expert and users using Likert scale with the value used are 5 to 1 . The results of the validation by theory expert get score 5 with a very worthy category, while the validation by media expert gets score 4.89 with the very worthy category. Whereas in the usage test by users or students and teacher response as an education practitioner showed very worthy category with scores 4.53 and 5 respectively. As a result, the developed pakakala boardgame for year 4 students at SDN 84 Parepare is suitable to use in teaching theme 4 concerning various occupations.
\end{abstract}

Keywords: learning media; the optional board; career cards; thematic learning; career guidance in primary school

\section{INTRODUCTION}

In order to prepare the high-quality Human Resources (HR) in the era of globalization, it is necessary to develop science and technology to collect information in order to have an impact on the development of life since Indonesia need human resources who have a high competitive spirit to face certain qualifications in the future. These efforts can be made through improving the quality of primary education. In the primary education, one aspect that needs to be done to prepare a generation that understands global needs is by providing career guidance.

Career guidance is an integral part of education that is inseparable from educational goals (Tilaar, 2009). Career guidance in primary school is a necessity so that students have a picture of their lives in the future. Even though career guidance in primary school has not been given a official formation, it needs to be given to students in order to improve career knowledge. The improved career knowledge can improve self-understanding, responsibility for selfcontrol, maturity in understanding the environment, and learning to make decisions (Tilaar, 2009).

Career is one aspect of human life to meet economic, social and psychological needs. Thus, career selection needs to be well prepared early on because it will have long-term effects on life. Since the school is a bridge to reach a career and teacher must help students to know, understand 
and begin to plan what they are become in the future

Career recognition in primary school needs to adjust to the existing career developments. The development in choosing a career includes three main stages, namely fantasy, tentative and realistic stages (Ginzberg, E., Ginsburg, S. W., Axelrad, S. \& Herma, 1951). For primary school students, they are at the fantasy stage. The career selection process is random on the reality that exists in only their impressions and fantasies. Career selection at this time is only based on the impression that results in pleasure and can be obtained from the people in their surroundings.

In year 4 students of SDN 84 Parepare (Public Primary School Number 84 Parepare), the researchers conducted observations and interviews on October 4, 2018. Researchers obtained results which showed that the career guidance process had not been given to year 4 students of SDN 84 Parepare. This results in a lack of career knowledge for students because of the lack of information conveyed by the teacher during the learning process. Researchers had an opportunity to conduct surveys using questionnaires which were able to collect the data showed that from 20 students, there were 31 types of careers identified while the average of most students knew 5 career merely. The occupations familiar to the students are those they can find around, instead, there are many career choices that they need to know in the future. In addition, the researchers also collected data on the reasons for choosing a career that is the pride of the community in their environment. There are also some students who choose careers for personal reasons, such as to treat their parents or to guard the family from danger.

The process of career guidance needs to be carried out to give a sense of awareness earlier about career choices that will be taken. This is in line with the visions of education; to grow and find interests and talents of students in order to prepare them as individuals who are able to adapt to the needs in the future. Career guidance needs to be given to year 4 students since it is in accordance with the 2013 curriculum that contains thematic learning about occupations around them. One way that is considered to be an alternative in the career guidance process is by using learning media. Learning media that can be used in primary school is in the form of game-based learning media because it should be interesting, enjoyable, encouraging curiosity, educating, activating interests and developing creativity.

For primary school students, learning media is a medium to visualize abstract theory to concrete as well as to overcome the limitations of students' experience (Triastuti, D., Akbar, S., \& Irawan, 2017). In addition, from the point of view point of Gagne and Brigggs described learning media includes tools that can be physically used to deliver the contents of learning materials such as books, tape recorder, cassette tapes, video recorder, movies, slides, photos, images, graphics, television, computer, reality and models (Arsyad, 2017). Thus, based on the explanation from the experts above, the researchers concluded that learning media is a tool that can be physically used to facilitate the delivery of ideas or contents of learning materials.

Teachers can develop their own learning media according to students' needs. In making and developing learning media, it is necessary to consider the cognitive development stage according to Piaget's theory, namely the sensorimotor stage $(0-2$ years old $)$, preoperational stage ( $2-7$ years old), concrete operational stage ( 7 - 11 years old), formal operational stage $(11-15$ years old) in resumed (Susanto, 2014). Primary school students are in the concrete operational stage. At this age, students can understand the message through pictures and direct activities (Ibda, 2015).

Primary school students love learning by playing. Primary school children like activities that are fun, enjoyable and it have game values (Hariyanto, 2009). To make the learning process interesting for them, it is necessary to build fun atmosphere for the convenience of learning. Teacher are required to develop learning systems that are in accordance with the need of students. One of the needs is the usage of learning media based on learning style of students. Learning media have to consider the characteristics of students (Mustafida, 2013). Education and developmental, that, at the final age, children are classified into four major groups, namely self-help, social help, social skills and playing skills (Baharuddin, 2017). One of the things that can be done to make students learning while playing is by modifying the game media into learning media (Sunar, 2008).

In the research conducted by (Hanani, 2016) in developing and using learning media in the form of career cards as a substitute for 
counseling teachers at SD Negeri Samirono (Samirono Public Primary School), it was found that in the use of career cards as learning media, students could more easily recognize the occupations in the card series he made. This is because children unconsciously learn through the process of playing. Learning while playing using games is one of the things that attracts researchers to conduct this study. From many kinds of games, boardgames are one of the interesting media that can be modified into learning media that are familiar to children and easy to use. There are so many findings about the effectiveness of boardgame. The usage of game gives greater understanding compare to conventional education method (Reid et al., 2012). Besides, conventional learning teacher centered have been complemented with student centered like game to allow the student ability to do self-learning (Zapata J. \& Awad-Aubad, 2007). In addition, boardgame is a vital instrumnet to provide hands-on and heads-on aptitude and information advancement for people on all subject and it is very useful, viable and suitable for all ages (Cook \& Olson, 2006).

Boardgames tend to make learning interesting and are very suitable for the purpose of education, at this time, it was not a teachercentered but interactive student-centered learning. Board games can be modified according to thematic learning. In the 2013 thematic syllabus for year 4 students, the carrier guidance is included as materials in a theme 4 concerning kinds of occupation. Based on this issue, the researchers were interested in trying to develop a learning media in the form of boardgame to improve students' career knowledge in fun, interactive and active learning under a title of "Development Learning Media of Pakakala Boardgame (Optional Board and Career Cards) in Year 4 Students of SDN 84 Parepare." Boardgame was chosen due to the ability to adapt to students' various learning styles. Another reason was that boardgame learning media can achieve learning objectives in accordance with the various themes of various jobs. This boardgame-based learning media was developed to find out the validity and attractiveness of its usability in year 4 students of SDN 84 Parepare.

\section{METHOD}

In this study, the researchers used ADDIE development model because it was more general and in accordance with the objectives of the media development to be carried out. ADDIE Model is an acronym for Analysis, Design, Development, Production, Implementation or Delivery and Evaluation. This model was chosen since it has some advantages, such as; dynamic and flexible in accordance with the needs needed by the researchers (Ariyanto, 2014). In this study, the researchers only used 3 (three) stages, namely Analysis, Design and Development due to the limited time, research needs and costs.

At the analysis stage, there were some analysis conducted on the needs of students, contents and formulation of objectives. The design stage consisted of product design, preparation of rules and game instruments and product assessment instruments. The development stage consisted of product making, expert validation (consisting of media experts, material/content experts, practitioners/teachers and students), as well as revisions obtained from suggestions and criticisms from the experts (validators) through a questionnaire. The score obtained was then made in percentage to determine the feasibility of learning media based on the following reference table.

Table 1. Media Feasibility Criteria

\begin{tabular}{lll}
\hline No & $\begin{array}{l}\text { Score in Percent } \\
(\%)\end{array}$ & $\begin{array}{l}\text { Feasibility } \\
\text { Criteria }\end{array}$ \\
\hline 1 & $81 \%-100 \%$ & Very Worthy \\
2 & $61 \%-80 \%$ & Worthy \\
3 & $41 \%-60 \%$ & Enough \\
4 & $21 \%-40 \%$ & Not Worthy \\
5 & $0 \%-20 \%$ & Very Unworthy \\
\hline
\end{tabular}

(Source : Arikunto, 2009

\section{RESULTS AND DISCUSSION}

\section{Results}

The developed product was then tested for product feasibility by the validators/validation experts. There were 4 kinds of validations, namely material expert validation, media expert validation, teacher validation and responses from year 4 students of SDN 84 Parepare. The data obtained were then analyzed for its feasibility to find out the media feasibility criteria 
Table 2. Results of Material Expert Validation

\begin{tabular}{lllc}
\hline No & Aspect & \multicolumn{1}{c}{ Score V1 } & Score V2 \\
\hline 1 & Content Feasibility & 4,5 & 5 \\
2 & Language & 4,67 & 5 \\
3 & Display & 4,5 & 5 \\
4 & Guidance Objectives & 4,67 & 5 \\
\hline \multicolumn{2}{c}{ Average } & 4,59 & 5 \\
\hline
\end{tabular}

Description: V1 = Validation stage 1; V2 = Validation stage 2

Table 2 shows the results of material expert validation. Based on the calculation, the assessment made by the material experts in the first stage shows the average results of 4.59 which was converted to $91.8 \%$, based on Table
1 , categorized as very feasible. The assessment of the second validation was obtained by obtaining an average of 5 which was converted to $100 \%$, categorized as very feasible

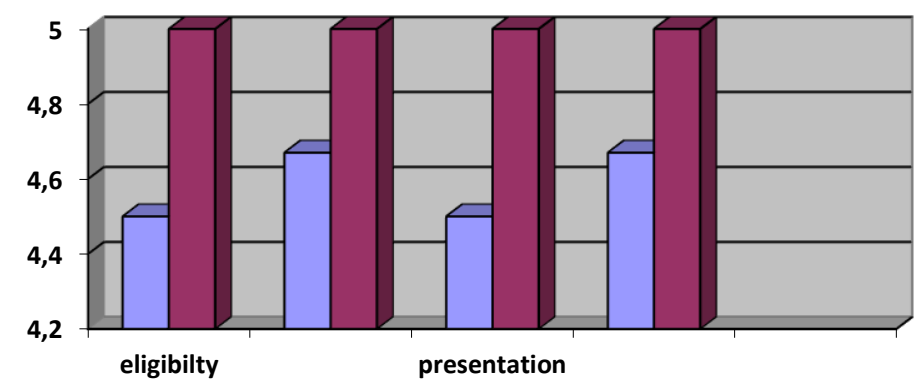

$\square$ first validation

$\square$ second validation

Graphic 1. Comparison between the Results of Material Expert Validations

Table 3. Results of Media Expert Validation

\begin{tabular}{|c|c|c|c|}
\hline No & Aspect & Score V1 & Score V2 \\
\hline 1 & Graphic Design of Media & 5 & 5 \\
\hline 2 & Physical Appearance of Package & 4,2 & 4,8 \\
\hline 3 & Graphic Design of Package & 1 & 5 \\
\hline 4 & Physical Appearance of Career Cards & 5 & 5 \\
\hline 5 & Physical Appearance of Boardgame & 2,6 & 5 \\
\hline 6 & Ease of Use & 4,5 & 5 \\
\hline 7 & Artistic Formation & 5 & 5 \\
\hline 8 & Usability & 4,5 & 5 \\
\hline 9 & Supporting Capacity & 5 & 5 \\
\hline \multirow[t]{2}{*}{10} & Rules & 5 & 5 \\
\hline & Average & 4,18 & 4,98 \\
\hline
\end{tabular}

Description: V1 = Validation stage 1; V2 = Validation stage 2

Table 3 shows the results of media expert validation. Based on the calculation, the assessment of media experts in the first stage shows an average of 4.18 which was converted to $83.6 \%$, based on Table 1 , categorized as very feasible. The assessment on the second validation was obtained with the increasing average of 4.98 which was converted to $99.6 \%$, categorized as very feasible category.
Based on the assessment of media and material experts, then Pakakala boardgame learning media is very feasible to be tested. The experiment is a follow-up process after validation to find out whether the developed learning media able to reach the objectives of development or not. The objective of developing Pakakala boardgame as learning media is to be able to achieve the learning objectives, namely 
the introduction of the kinds of careers that are appropriate to theme 4 concerning various occupations. The experiment aimed to discover the strengths and weaknesses of the process that can be related to the theory of learning media. This experiment stage is different from the implementation stage in the ADDIE theory. This stage was only aimed to see how students and teachers/practitioners respond to Pakakala boardgame learning media developed in the study. From the experiment conducted to 20 year 4 students of SDN 84 Parepare, the average response was 4.53 which was converted to $90.6 \%$, based on Table 1, categorized as very feasible.

Table 4. Results of Teachers' Responses

\begin{tabular}{llc}
\hline No & Aspect & Score \\
\hline 1 & Media & 5 \\
2 & Material & 5 \\
3 & Language & 5 \\
4 & Students' acitivities when using & 5 \\
& the media & 5 \\
\multicolumn{2}{c}{ Average } \\
\hline
\end{tabular}

The responses shown by the teacher in the experiment of Pakakala boardgame learning media obtained the results of 5 , categorized as "Very Feasible". The researchers also interviewed the teachers during the experiment process. The teachers considered learning media is very interesting and needs to be improved because it can improve students' interest and participation in the learning process. The Pakakala boardgame learning media was also assessed by the teachers to ease the workload of the teacher since the students can use it independently without the help of a teacher. The teachers added that even though it attracts students' interest but learning media can cause noisy condition to the class. It will give another task to the teachers to keep the learning situation conducive without disturbing other classes

\section{Discussion}

After obtaining the data about the problems and the needs of learning media that are suitable for year 4 students, the researchers tried to find relevant theories. The theories are related to the types of learning media that are in accordance with the conditions or characteristics of year 4 students who are in concrete operation. There is also a theory about choosing career development in students/children. Year 4 students are in the fantasy stage where the career selection process is random about the reality that exists in only impressions and fantasies. Career selection at this time is only based on the impression that results in pleasure and can be obtained from the people in their surroundings.

Based on the general theory, researchers designed a game-based learning media in accordance with the data collected from a questionnaire distributed to year 4 students of SDN 84 Parepare. There are several types of game-based learning media proposed in (Seels, B., \& Glasgow, 1998), such as puzzles, simulations, boardgames and cardgames. Researchers chose to develop a boardgamebased learning media because according to (Cook \& Olson, 2006), boardgames provide hands-on and heads-on aptitude and information advancement for people on all subject and it is very useful, viable and suitable for all ages. Futhermore, the development of game based learning gives student motivation and involment in each activity which could make learning process successful (Anastasiadis et al., 2018). In addition, by using games children can better in absorbing learning material (Rachman et al., 2019) Boardgames tend to make learning interesting and are very suitable for the purpose of education, at this time, it was not a teachercentered but interactive student-centered learning. Boardgames can be modified according to thematic learning.

After making the initial design, the media and material/content experts then conducted validation to it. According to the validators, the developed product has met the criteria. This is supported by the results of the material and media/content validation that direct researchers to revise until the developed products meet the criteria. The Pakakala boardgame has met several criterias according to (Sisiliana, 2008) that the media is appropriate and in accordance with its objectives. The purpose of developing Pakakala boardgame learning media is that the delivery or learning process in theme 4 in year 4 class is directed, uniform and attracts students' interest also in accordance with the objectives of the material objectives.

The results of the assessment are in accordance with the identification of the benefits of learning media that it delivery of material becomes uniform, clear, interactive and interesting, makes time and energy efficient and improves the quality of student learning 
outcomes (Solihatin, 2012). Based on the content of learning material, the material is in accordance with the contents of the theme 4 . Suitability of learning media with the characteristics of year 4 students of primary school who have curiosity, love to play, actively move and ask questions. The use of learning media is adjusted to the hours of learning provided and can also be used outside of learning hours as a source of learning and entertainment for students.

The results of the material expert validation at the final stage obtained a score of 5 , categorized as very feasible. The media expert validation obtained a result of 4.98 , categorized as very feasible. The students' responses on the experiment showed a result of 4.53 , categorized as very feasible. Teachers' responses as an education practitioner, showed a result of 5, categorized as very feasible. The product developed by researchers has quality improvements both in terms of contents, materials and forms of learning media resulted from the validation or advice given by experts at both stages.

Pakakala Boardgame is efficient and easy to carry as a learning media, creating a different learning atmosphere and its use safely used by students independently based on the result of observations that researchers get during the experiment. The results of the experiment observed by the researchers showed students were very enthusiastic and gained new knowledge about the types of career choices. Based on this result, it can be concluded that students enjoy the learning process. Primary school students like activities that are fun, full of fun and full of game values. To make the learning process interesting for them, it is necessary to build fun atmosphere for the convenience of learning.

Based on the experiment of using Pakakala boardgame as learning media which was conducted on year 4 students of SDN 84 Parepare, there was improvement in career knowledge. It is based on observations when students answer questions from cards on the boardgame. The work that was not previously written on students' career knowledge in the preresearch questionnaire can be answered after answering questions that mention the occupations, workplaces and characteristics.

Based on the whole process that has been carried out by researchers starting from the pre-research and research, the development of
Pakakala boardgame as learning media (optional board and career cards) shows changes in the learning process. The changes start from verbalism teaching technique to be active, interactive and fun. The researcher also observed students trying to be more independent in answering questions. The process of discovery learning and group discussion takes place to answer questions on career cards. In (Orowala, 2017) regarding the benefits of learning media. The benefits of learning media are: (1) Interesting and grabbing students' attention to the materials; (2) Reducing and even eliminating verbalism; (3) Overcoming differences in learning experiences based on the socio-economic background of students; (4) Providing new learning experiences; (5) Overcoming the boundaries of space and time; (6) Helping students to develop their minds regularly; (7) Growing student's own business skills based on experience and reality; (8) Enabling direct contact between students and teachers, the community and the surrounding environment.

Based on the stages that have been done, it can be concluded that this development study has achieved the desired goal, namely to produce a feasible career card as a learning media for students in year 4 class of SDN 84 Parepare.

The success of researchers in developing educational games has also carried out and proven by previous researchers : Hanani (2016) in her research entitled "The Development of Career Cards as Media in Guiding Students' Career at SD Negeri Samirono" has also used as an alternative learning media means of learning career options at SD Negeri Samirono. Hanani (2016) focuses on young learner students. In her research, Zati Hanani recounted that SDN Sami students had difficulty in recieving information due to unmatched characterictics of learning media showed. Therefore, she built a learning media in card type that could help students in gaining career information by playing based that matched with students characteristic who love playing. Then students finally managed to learn certain career options eventhough it have several shortages.

While Amin Listyani (2017), in her research entitled "Development of Snake and Ladder Boardgame Based on Cultural Diversity for 3rd Grader Students SDN Kotagede 5 Yogyakarta" did the same thing, where she developed game based learning because the 
monoton way in teaching students. She developed games because it is matched with the way students / children learn without have to being pushed.

Learning media supposed to be more interactive and attracted for students in case to gain their learning experience. The researchers succeeded in developing a game based learning in boardgame type to extend the way teacher in primary school teaching. By research though theory and previous research product developed, finally the researchers made and developed games in boardgame type named pakakala (the optional board and career cards). The pakakala boardgame attractes students by its physical look, build their motivation to know more career options and add the way teacher teaching in the class especially for year four students in primary school.

\section{CONCLUSIONS AND SUGGESTIONS}

The need to develop boardgame learning media in SDN 84 Parepare is for making variations in the learning process. The 2013 curriculum requires teachers to be creative and innovative in making the learning process to be interactive.

The results of the study showed that the validation by material experts is categorized as very feasible (5.0), while the results of the validation by media experts showed that the product is very feasible (4.98). The results of the responses on the experiment showed the product is categorized as very feasible (4.53). The results of the teachers' responses as an education practitioner on the experiment showed that the product is categorized as very feasible (5.0).

Based on these results, the developed Pakakala boardgame for year 4 students at SDN 84 Parepare (Primary School) is suitable to use in learning the theme 4 concerning various occupations. The researchers suggested that the Pakakala boardgame can be used as learning media by the teachers in year 4 class as the materials for theme 4 concerning various occupations in order to create variations in the learning process.

\section{REFERENCES}

Anastasiadis, T., Lampropoulos, G., \& Siakas, K. (2018). Digital Game-based Learning and Serious Games in Education. International Journal of Advances in
Scientific Research and Engineering, 4(12), 139-144. https://doi.org/10.31695/ijasre.2018.33016

Ariyanto, F. (2014). Peningkatan Prestasi Belajar Matematika Melalui Model Pembelajaran ADDIE Pada Siswa Kelas V SD Muhammadiyah Pati Tahun 2014/2015. IKIP PGRI Semarang.

Arsyad, A. (2017). Media Pembelajaran. Jakarta. PT. Rajagrafindo Persada.

Baharuddin. (2017). Pendidikan dan Psikologi Perkembangan. Arruzz Media.

Cook, L. S., \& Olson, J. R. (2006). The sky's the limit: An activity for teaching project management. Journal of Management Education, 30(3), 404-420. https://doi.org/10.1177/105256290527922 0

Ginzberg, E., Ginsburg, S. W., Axelrad, S. \& Herma, J. L. (1951). Occupational Choice: An approach to a general theory. Colombia University Press.

Hanani, Z. (2016). Pengembangan Kartu Karir Sebagai Media Bimbingan Karir Siswa SD. E-Journal Bimbingan Dan Konseling, 9, 313-326.

Hariyanto, A. (2009). Membuat Siswa Anda Cepat Pintar Membaca. Diva Press.

Ibda, F. (2015). Perkembangan Kognitif Teori Jean Piaget. Jurnal Ilmiah Intelektualita, 3(1).

Mustafida, F. (2013). Kajian Media Pembelajaran Berdasarkan Kecenderungan Gaya Belajar Peserta Didik SD/MI. Jurnal Madrasah, 6, 77-95.

Orowala, S. M. (2017). Pengembangan Media Ular Tangga pada Materi Pokok Mengenal Bangun Datar dalam Subtema Anggota Keluargaku untuk Siswa Kelas 1 Sekolah Dasar. Universitas Sanata Dharma.

Rachman, A., Purwanto, M. Y., \& Nugroho, H. (2019). Development of Educational Games for The Introduction of Fruits and Vitamins. Journal of Educational Science and Technology (EST), 5(1), 76-81. 
https://doi.org/10.26858/est.v5i1.8495

Reid, M., Brown, S., \& Tabibzadeh, K. (2012). Capstone Teaching Models: Combining Simulation, Analytical Intuitive Learning Processes, History and Effectiveness. Journal of Education for Business, 87(3), 178-184.

https://doi.org/10.1080/08832323.2011.58 6006

Seels, B., \& Glasgow, Z. (1998). Making instructional design decisions. Merrill/Prentice Hall.

Sisiliana, C. R. \& R. (2008). Media Pembelajaran Hakikat, Pengembangan, Pemanfaatan dan Penilaian. Jurusan Kurtekpen FIP UPI.

Solihatin, E. (2012). Strategi Pembelajaran. Bumi Aksara.
Sunar, D. P. (2008). Rahasia Mengajarkan Gemar Membaca pada Siswa Sejak Dini. Think.

Susanto. (2014). Teori Belajar dan Pembelajaran di Sekolah Dasar. Prenadamedia Group.

Tilaar. (2009). Membenahi Pendidikan Nasional. PT.Asdi Mahasatya.

Triastuti, D., Akbar, S., \& Irawan, E. B. (2017). Pengembangan Media Papan Permainan Panjat Pinang. Jurnal Pendidikan: Teori, Penelitian, Dan Pengembangan, 2, 13441350.

Zapata J., C. M., \& Awad-Aubad, G. (2007). Requirements Game: Teaching Software Project Management. CLEI Electronic Journal, https://doi.org/10.19153/cleiej.10.1.3 $10(1)$. 